Bondarenko, B.I., Kozhan, O.P., Dmitriev, V.M., Rjabchuk, V.S., Strativnov, E.V., and Simeiko, K.V.

The Gas Institute of the NAS of Ukraine,

39, Degtyarivska St., 03113, Kyiv, Ukraine, +380 $0444564471,+38004445688$ 30, k_simeyko@ukr.net

\title{
DEVELOPMENT OF TECHNOLOGY AND TRIAL PRODUCTION OF EXTREMELY HIGH RESISTANT NANOPOROUS GRAPHITE SEALERS FOR NUCLEAR REACTORS
}

Introduction. As a result of termination of cooperation with Russian Federation, it became necessary to diversify supplying not only nuclear fuel, but also goods and materials for assembly, operation, technical maintenance, and repair of power engineering equipment.

Problem Statement. Critically important products include, in particular, gaskets for sealing the plug-type connections of reactor units with water-cooling equipment, for example, ПГВ-1000M steam generators. For the time being, the existing reserves of TEG (thermally expanded graphite) gaskets imported from Russia for upgraded steam generators ПГВ-1000M and ПГВ-213 have been almost exhausted, therefore there is an urgent need for the domestic production of these and other TEG sealers.

Purpose. Development of technological framework for manufacturing TEG sealers for the NPP technological equipment.

Materials and Methods. Graphite foil of different manufacturers obtained from original natural graphite, conventional methods for measuring the physico-technical characteristics of sealing gaskets.

Results. Within the framework of the conducted R\&D works, the physical, technical, and physicochemical properties of graphite foils made of natural graphite derivatives by various manufacturers have been established; molds of two standard sizes have been designed and manufactured; the technology for molding the sealers from graphite foil has been tested; specific compression force to obtain the sealers of given density has been determined; specific compression strength of the obtained gaskets has been established.

Conclusion. The obtained results can be used for developing a new pilot manufacture of TEG sealing gaskets by domestic corporations.

Keywords: thermally expanded graphite (TEG), nuclear power plants, process equipment, and sealers.

The problem of leak proofness of the plug-type connections of reactor plants has been among the most urgent ones in designing, manufacturing, operating, and repairing NPP equipment. Depressurization can lead to accidents involving the release of radioactive coolant outside the corresponding loop of the reactor plant, as well as cause corrosion damage to the reactor plant

(C) BONDARENKO, B.I., KOZHAN, O.P., DMITRIEV, V.M., RJABCHUK, V.S., STRATIVNOV, E.V., and SIMEIKO, K.V., 2018 structural elements. The strength and tightness of sealers is a precondition for trouble-free operation of reactor plants.

Traditionally, almost all plug-type connections were sealed with nickel rings. As ring is compressed, nickel, due to its properties, hardens as result of strain and becomes as hard as the sealing surfaces of plug-type joint flanges, which are made mainly of austenitic steel $08 X 18 \mathrm{H} 10 \mathrm{~T}$ or have a surfacing made of this steel. Tightening results in plastic deformation of the sealing sur- 
faces, which changes their geometry. Over the years, these processes are intensified, plastic deformations are accumulated, and the seal assembly loses its tightness. The sealing surfaces need to be repaired to restore their design geometry, but this does not always lead to a positive result. In the early 1990s, leakages of plug-type connections of WWPR (water-water power reactor) plants occurred massively, which led to NPP forced outages until the joints were resealed. The technological principle of manufacturing the sealing elements made of graphite foil obtained by thermally expanded graphite (TEG) rolling is based on the results of research carried out at Joint-Stock Company Research Design Bureau HYDROPRESS (Russia) and aiming at upgra- ding seal assemblies of steam generators PGV440 and PGV-1000M [1-9].

Five samples of TEG foil from three manufacturers have been used while studying the technology for compression of TEG sealing elements, at the Institute of Gas of the NAS of Ukraine:

a) FG-IG graphite foil manufactured at the Institute of Gas of the NAS of Ukraine. The foil is made of TEG made at and using the technological equipment of the Institute of Gas of the NAS of Ukraine. TEG is obtained from oxidized graphite of Zavalievsky graphite plant, using the technological equipment of the same institute. The technology for obtaining TEG is described in [10,11];

b) TMG-F/V2 graphite foil manufactured by LLC TMSpetsmash (Kyiv, Ukraine) made of TEG

Physical, Technical, and Chemical Properties of Graphite Foil Samples used in Experiments

Table 1 for Improving the Technology for Manufacturing Sealing Gaskets

\begin{tabular}{|c|c|c|c|c|c|}
\hline \multirow{2}{*}{ Parameter } & \multicolumn{5}{|c|}{ Type of graphite foil } \\
\hline & FG-IG & TMG-F/V2 & GF-1 & GF-2 & GF-3 \\
\hline Appearance & $\begin{array}{c}\text { TU U 26.8- } \\
30969031-002- \\
2002 *\end{array}$ & $\begin{array}{c}\text { TU U 26.8- } \\
\text { 30969031-002- } \\
2002 *\end{array}$ & $\begin{array}{c}\text { TU U 26.8- } \\
\text { 30969031-002- } \\
2002 *\end{array}$ & $\begin{array}{c}\text { TU U 26.8- } \\
\text { 30969031-002- } \\
2002{ }^{*}\end{array}$ & \begin{tabular}{|} 
TU U 26.8- \\
30969031-002- \\
$2002 *$
\end{tabular} \\
\hline Thickness, mm & $0,19-0,22$ & 0,42 & 0,51 & 0,53 & 0,21 \\
\hline Density, $\mathrm{g} / \mathrm{cm}^{3}$ & 0,98 & 1,01 & 1,0 & 0,82 & 0,91 \\
\hline Carbon content, wt \% & 99,0 & 99,3 & 98,7 & 97,8 & 97,7 \\
\hline Ash residue content, wt \% & 0,07 & 0,44 & 0,84 & 1,9 & 1,9 \\
\hline Sulfur content, wt \% & 0,10 & 0,11 & 0,12 & 0,12 & 0,12 \\
\hline $\begin{array}{l}\text { Tensile strength along the rolling } \\
\text { axis, } \mathrm{MPa}^{* *}\end{array}$ & $3,3-4,2$ & $4,2-5,0$ & $3,7-3,9$ & $3,3-3,5$ & $3,5-4,0$ \\
\hline $\begin{array}{l}\text { Tensile strength across the rolling } \\
\text { axis, MPa }\end{array}$ & $2,7-2,9$ & $4,0-4,9$ & $3,4-3,7$ & $3,0-3,2$ & $3,1-3,9$ \\
\hline $\begin{array}{l}\text { Electric resistance along the rolling } \\
\text { axis, ohm } \bullet \mathrm{m}\end{array}$ & $7,1 \times 10^{-6}$ & $8,2 \times 10^{-6}$ & $6,6 \times 10^{-6}$ & $7,4 \times 10^{-6}$ & $7,1 \times 10^{-6}$ \\
\hline $\begin{array}{l}\text { Compressive ratio in a free state, } \\
\text { under a pressure of } 35 \mathrm{MPa}, \%\end{array}$ & 37,0 & 36,0 & 34,0 & 37,0 & 35,0 \\
\hline $\begin{array}{l}\text { Restorability after release of pressure } \\
\text { of } 35 \mathrm{MPa}, \%\end{array}$ & 11,0 & 14,0 & 12,0 & 15,0 & 14,0 \\
\hline
\end{tabular}

* - foil surface is flat, smooth, having neither nicks, nor scratches, nor ruptures, nor burns, nor buckles, nor laps, nor corrugations, nor foreign impurities; ** - limiting values obtained for 5 samples. 


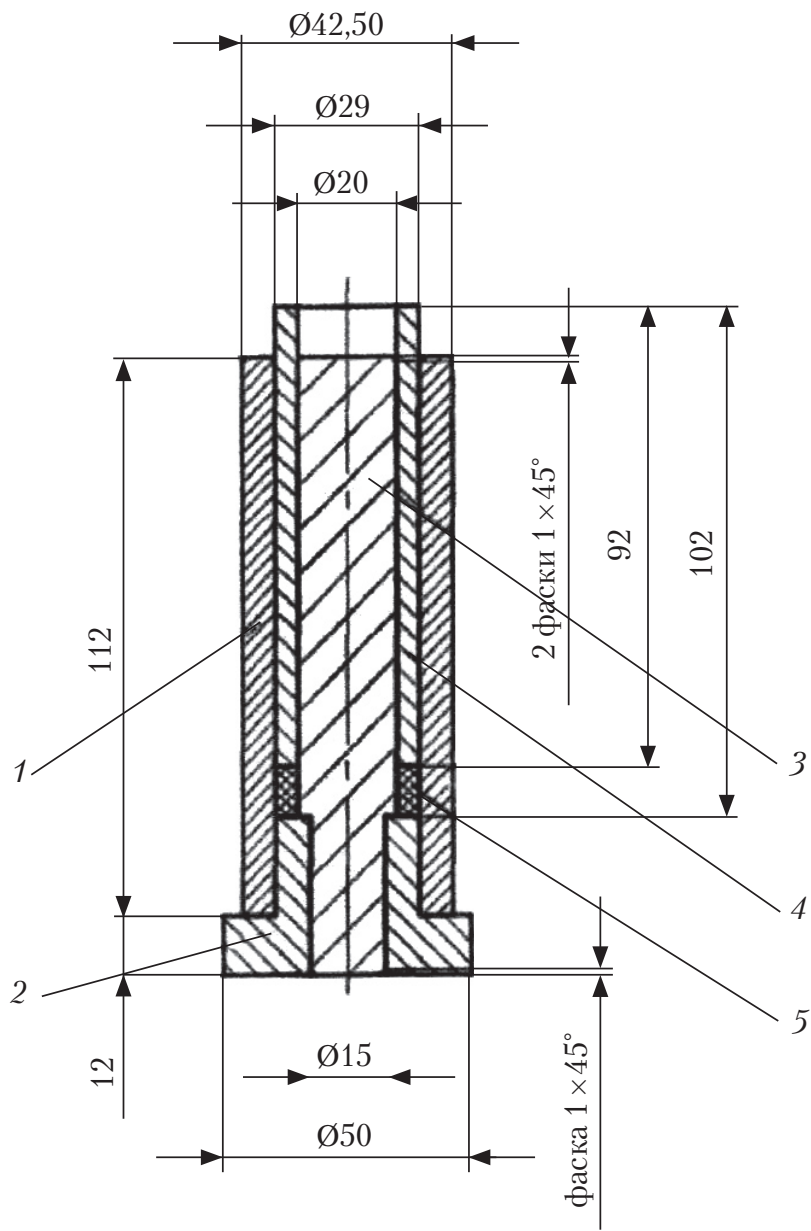

Fig. 1. Mold prototype of standard size 1:1 - outer chase; 2 - supporting ring; 3 - inner chase; 4 - plug; 5 - gasket

of its own production, by rolling, without binder; TEG is obtained from oxidized graphite produced in China;

c) GF-1, GF-2, GF-3 graphite foils supplied by BONUM GROUP LLC (Zaporizhzhia, Ukraine), manufactured by Yichang Xincheng Graphite Co., Ltd., China; meet the requirements of the $\mathrm{XC}$ 120109 standard.

The physical, technical, and physicochemical characteristics of graphite foil GF measured in the course of study are given in Table 1 .

Experimental samples of gaskets are made using press molds of standard sizes (Figs. 1, 2).

The graphite foil is wound into rolls on inserts having a diameter over $90 \mathrm{~mm}$. The roll length must exceed the width of the foil, at least, by $10 \%$. The roll mass is not regulated. Before pressing, the graphite foil is cut into strips having a width of $20-25 \mathrm{~mm}$, with the total length of the strip segments corresponding to a given mass of gasket based on the density of the gasket material $\left(1.80 \mathrm{~g} / \mathrm{cm}^{3}\right)$.

The graphite foil strips of appropriate length are wound around the rod of press mold manually, keeping the required winding density. Further, a certain mechanical method for winding will be provided for molds having dimensions meeting the specification requirements.

For pressing the sealing gaskets, hydraulic press with a working table of required dimensions and a compression force indicator is used. The specific compression force is $150 \mathrm{MPa}$. After the end of compression, the gasket is held in the press mold, in compressed state for 5-10 additional seconds to prevent a high rebound after the release of pressure. The finished gasket is treated with fine-grained abrasive material to remove scratches and tears.

For each type of source material, 15 gasket samples are made, 5 of which are used for measuring the ultimate compressive strength, and 10 samples are used to determine the density characteristics of gaskets.

The ultimate compression strength of TEG gasket prototypes is measured in accordance with TU 5728-006-12058737-2005 "Sealing gaskets of thermally expanded graphite". The method provides for applying the axial load to the prototypes located between two parallel supports, until the prototype is destroyed. The tests are carried out at a temperature of $20{ }^{\circ} \mathrm{C}$. The gasket is placed between the two supports. The load is applied smoothly (without shocks) until the prototype is destroyed. The maximum load $(Q)$ recorded before the prototype is destroyed is used to determine the ultimate compression strength.

The ultimate compression strength $\sigma_{\text {ст }}$ ) in $\mathrm{MPa}$, is calculated by the formula:

$$
\sigma_{\text {ст. }}=Q / F_{0}
$$


where $Q$ is maximum load recorded before the prototype destruction, $\mathrm{N} ; F_{0}$ is prototype's working surface area, $\mathrm{mm}^{2}$.

The ultimate compression strength value has been determined as arithmetic mean of tests of 5 prototypes.

The test results are shown in Table 2 .

The ultimate compression strength of $H Y$ DROPRESS gasket prototype is $9.5 \mathrm{MPa}$, which ensures the proper density of plug-type connections of NPP technological equipment.

The aforementioned research has been carried out at the research base of the Institute of Gas of the NAS of Ukraine, using the existing technological equipment. The tests at a pressure of 350 $\mathrm{kg} / \mathrm{cm}^{2}$ have been done on the test stand of ATOMPRILAD Design Bureau of Energoatom National Atomic Energy Company. The mold for making TEG gaskets for steam generator PGV$1000 \mathrm{M}$ has been designed and manufactured at the Brovary Plant of Powder Metallurgy. The gasket prototype manufactured at the same plant completely fits the seal assembly of the steam generator. This means the design is based the correct assumption of the gasket expansion after its removal from the mold. Currently, at Atomenergomash, where the necessary production facilities and equipment are available, there are created a complete cycle for manufacturing the TEG gaskets. In the test mode of production site operation, several samples of sealing gaskets having standard dimensions have been made.

According to the research results, a technology for manufacturing the TEG sealing gaskets by pressing a semi-finished product, the graphite foil

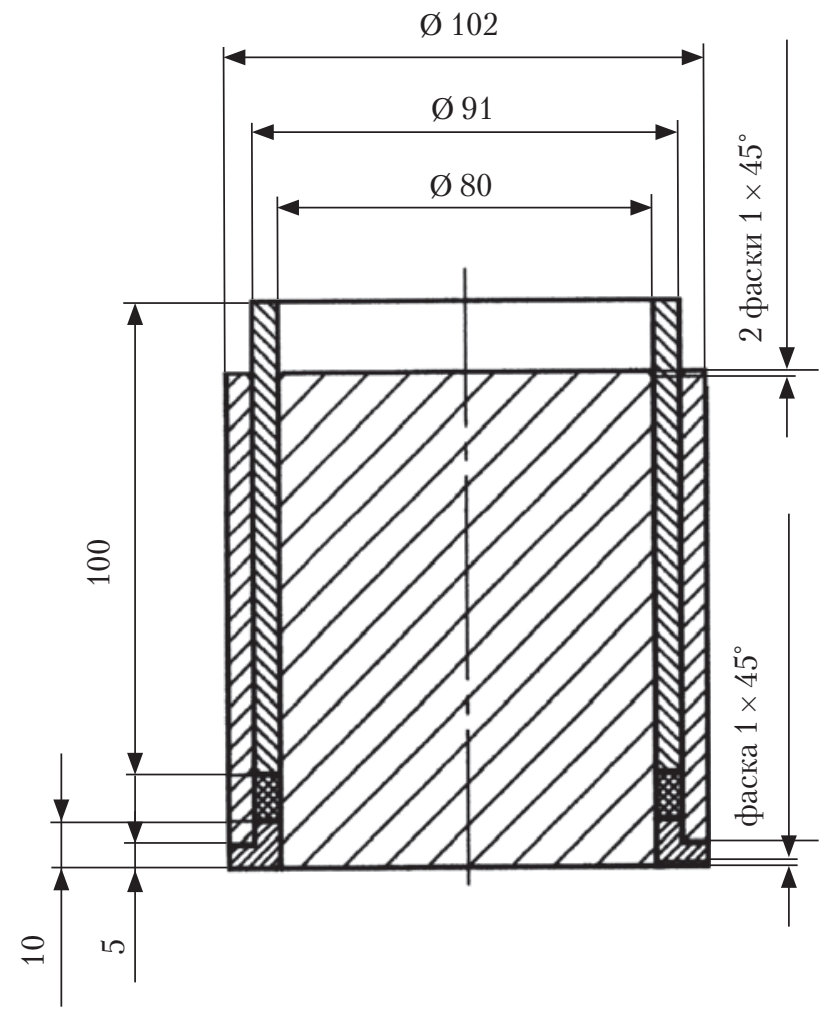

Fig. 2. Mold prototype of standard size 2

has been developed. The physical and chemical characteristics of graphite foil and their influence on the properties of finished products have been studied.

The tests of TEG gasket prototypes have shown that their mechanical strength is $30-35 \%$ lower than the strength of the previously used TEG gaskets manufactured by HYDROPRESS (Russia). It has been established [12] that pretreatment of the derivative graphite foil by in-

Ultimate Compression Strength of TEG Gasket Prototypes

Table 2

\begin{tabular}{|c|l|c|c|c|c|c|}
\hline \multirow{2}{*}{ № } & \multicolumn{1}{|c|}{ Parameter } & \multicolumn{5}{|c|}{ Type of graphite foil } \\
\cline { 3 - 6 } & \multicolumn{1}{|c|}{ FG-IG } & TMG-F/V2 & GF-1 & GF-2 & GF-3 \\
\hline 1 & $\begin{array}{l}\text { Ultimate compression strength ( } \sigma_{\text {cr }} \text { ), of } \\
\text { standard size 1 gasket, MPa }\end{array}$ & 6,47 & 6,20 & 5,46 & 6,76 & 6,45 \\
$\begin{array}{l}\left.\text { Ultimate compression strength ( } \sigma_{\text {cr }}\right), \text { of } \\
\text { standard size 2 gasket, MPa }\end{array}$ & 6,09 & 6,11 & 5,77 & 6,55 & 6,77 \\
\hline
\end{tabular}

ISSN 1815-2066. Nauka innov. 2018, 14(5) 
creasing the roughness of its surface enables a $20-30 \%$ increase in the mechanical strength of the gaskets.

While manufacturing the gasket prototype of standard size for the steam generator PGV-213 it has been established that the gasket expansion after its removal from the mold corresponds to the results of previous studies.

Today, the Institute of Gas of the NAS of Ukraine continues research works to improve the mechanical strength of gaskets by pretreatment of graphite foil, in particular, by increasing the surface roughness. Based on the results, the patent of Ukraine for invention [12] has been received and two applications for the patent of Ukraine have been filed.

The research results are used to create a production site for manufacturing TEG gaskets at one of Energoatom enterprises, Atomenergomash. The implementation of the entire production cycle for manufacturing the TEG sealing gaskets will eliminate the import dependence of the country and increase the safety of the operation of domestic nuclear power plants.

\section{REFERENCES}

1. Konjushkov, A. G. (2007). Experimental study sites seals reactor plants with VVER. PhD (Tech.). Podolsk [in Russian].

2. Ryzhov, S. B. (2007). Development, calculation and experimental justification and pilot-industrial operation of VVER1000 reactor compaction units. $\mathrm{PhD}$ (Tech.). St. Petersburg [in Russian].

3. Rus'janov, V. G., Denisov, V. P., Dragunov, Ju. G., Seleznev, A. V., Ryzhov, S. B., Geront'ev, A. E., Konjushkov, A. G. (2004). Sealing device plug connections of equipment of reactor plants VVER. Moskva [in Russian].

4. Seleznev, A. V., Geront'ev, A. E., Konjushkov, A. G., Ryzhov, S. B. (2002). Development and introduction of seal assemblies with expanded graphite gaskets in the equipment of reactor units WWER. Annual report of FSUE OKB "Gidropress" for 2001. Main research and development work. Podolsk [in Russian].

5. Geront'ev, A. E., Strahov, A. A., Konjushkov, A. G., Alekseev, D. E. (2005). Modernizacija uplotnitel'nyh ustrojstv parogeneratorov PGV-440 i PGV-1000M s primeneniem prokladok iz rasshirennogo grafita. Voprosy atomnoj nauki i tehniki, 9 , 95-101 [in Russian].

6. Geront'ev, A. E., Strahov, A. A., Konjushkov, A. G., Alekseev, D. E. (2005). Modernizacija uplotnitel'nyh ustrojstv parogeneratorov AJeS s VVJeR-440, VVJeR-1000. Atomnaja jenergija, 6, 476-481 [in Russian].

7. Ryzhov, S. B., Konjushkov, A. G., Titov, O. V. (2005). Razrabotka, raschjotno-jeksperimental'noe obosnovanie i opytno-promyshlennaja jekspluatacija uzlov uplotnenij reaktorov tipa VVJeR-1000. Voprosy atomnoj nauki i tehniki, 9, 103115 [in Russian].

8. Konjushkov, A. G., Rus'janov, V. G., Geront'ev, A. E. (2004). Obshhie voprosy uplotnenij raz`emnyh soedinenij RU s VVJeR. Sbornik trudov FGUP OKB «Gidropress», 5, Part 2, 287-293 [in Russian].

9. Seleznev, A. V., Geront'ev, A. E., Konjushkov, A. G. (2001). Razrabotka i vnedrenie uzlov uplotnenij s prokladkami iz rasshirennogo grafita v oborudovanii reaktornyh ustanovok VVER. Sbornik trudov FGUP OKB «Gidropress», 2, Part 3, 435-439 [in Russian].

10. A. s. 1266103 SSSR. MKI4 C 01 B 34 / 04. Sposob poluchenija rasshirennogo grafita. B. E. Paton, A. P. Kozhan, V. K. Pikalov, K. E. Mahorin. No. 8513455/43; zajavl. 12.05.85; opubl. 22.06.86, bjul. No. 14 [in Russian].

11. Mahorin, K. E, Kozhan, A. P. (1987). Vspuchivanie grafita v plotnom i vzveshennom slojah. Himicheskaja tehnologija, 2, 14-19 [in Russian].

12. Patent of Ukraine N 115288. Bondarenko B. I., Kozhan A. P., Dmitriev V. M., Kul'chic'kij G. M., Rjabchuk V. S., Pisarenko I. O., Chernjuk L. M. Method of manufacturing of sealing elements from thermo-expanded graphite [in Ukrainian].

Received 02.03.18 


\author{
Б.І. Бондаренко, О.П. Кожан, В.М. Дмітрієв, \\ В.С. Рябчук, С.В. Стратівнов, К.В. Сімейко \\ Інститут газу Національної академії наук України, \\ вул. Дегтярівська, 39, Київ, 03113, Україна, \\ +380044 $4564471,+38004445688$ 30,k_simeyko@ukr.net \\ РОЗРОБКА ТЕХНОЛОГІЇ ТА СТВОРЕННЯ ДОСЛІДНОГО \\ ВИРОБНИЦТВА НАНОШАРУВАТИХ ГРАФІТОВИХ УЩІЛЬНЕНЬ \\ ЕКСТРЕМАЛЬНО ВИСОКОЇ СТІЙКОСТІ ДЛЯ ЯДЕРНИХ РЕАКТОРІВ
}

Вступ. У зв'язку з фактичним припиненням співпраці з Російською Федерацією, останнім часом виникла необхідність диверсифікації поставок не лише ядерного палива, але й виробів та матеріалів, необхідних для монтажу, експлуатації, технічного обслуговування та ремонту енергетичного обладнання.

Проблематика. До критично важливих виробів належать, зокрема, ущільнюючі прокладки для герметизації роз'ємних з'єднаннь обладнання реакторних установок з водо-водяним енергетичним реактором, наприклад, парогенераторів ПГВ-1000М. На сьогодні практично вичерпано наявні резерви раніше імпортованих з Росії прокладок 3 терморозширеного графіту (ТРГ) для модернізованих парогенераторів ПГВ-1000М та ПГВ-213 і має місце невідкладна потреба налагодження вітчизняного виробництва цих та інших ущільнюючих елементів з ТРГ.

Мета. Розробка технологічних засад виготовлення ущільнюючих елементів з ТРГ для устаткування АЕС.

Матеріали й методи. Графітова фольга різних виробників, що отримана з вихідного природного графіту. Стандартні методи визначення фізико-технічних характеристик ущільнюючих прокладок.

Результати. У рамках проведених досліджень та технологічних розробок було визначено фізико-технічні та фізико-хімічні властивості графітової фольги різних виробників, отриманої з похідного природного графіту. Розроблено та виготовлено прес-форми двох типорозмірів, апробовано технологію пресування ущільнюючих елементів з графітової фольги, визначено питоме зусилля пресування для одержання ущільнюючих елементів заданої густини. Встановлено показники щодо питомої міцності одержаних прокладок при стисканні.

Висновки. Отримані результати досліджень можуть бути використані для створення дослідного виробництва ущільнюючих прокладок з ТРГ на вітчизняних підприємствах відповідного профілю.

Ключові слова: терморозширений графіт, атомні електростанції, технологічне обладнання, ущільнюючі елементи.

\author{
Б.И. Бондаренко, А.П. Кожан, В.М. Дмитриев, \\ В.С. Рябчук, Е.В. Стративнов, К.В. Семейко \\ Институт газа Национальной академии наук Украины, \\ ул. Дегтяревская, 39, Киев, 03113, Украина, \\ +3800444564471,+3800444568830k_simeyko@ukr.net

РАЗРАБОТКА ТЕХНОЛОГИИ И СОЗДАНИЕ ОПЫТНОГО
ПРОИЗВОДСТВА НАНОСЛОИСТЫХ ГРАФИТОВЫХ УПЛОТНЕНИЙ
ЭКСТЕРМАЛЬНО ВЫСОКОЙ УСТОЙЧИВОСТИ ДЛЯ ЯДЕРНЫХ РЕАКТОРОВ

Введение. В связи с фактическим прекращением сотрудничества с Российской Федерацией, в последнее время возникла необходимость диверсификации поставок не только ядерного топлива, но и изделий и материалов, необходимых для монтажа, эксплуатации, технического обслуживания и ремонта энергетического оборудования.

Проблематика. К критически важным изделиям относятся, в частности, уплотнительные прокладки для герметизации разъемных соединений оборудования реакторных установок с водо-водным энергетическим ректором, например, парогенераторов ПГВ-1000М. В настоящее время практически исчерпаны имеющиеся резервы импортируемых из России прокладок с терморасширенного графита (ТРГ) для модернизированных парогенераторов ПГВ1000М и ПГВ-213 и имеет место острая необходимость налаживания отечественного производства этих и других уплотнительных элементов с ТРГ.

Цель. Разработка технологических основ изготовления уплотнительных элементов с ТРГ для оборудования АЭС.

Материалы и методы. Графитовая фольга различных производителей, полученная из исходного природного графита. Стандартные методы определения физико-технических характеристик уплотнительных прокладок.

Результаты. В рамках проведенных исследований и технологических разработок были определены физико-технические и физико-химические свойства графитовой фольги разных производителей, полученной из исходного при- 
родного графита. Разработаны и изготовлены пресс-формы двух типоразмеров, испытана технология прессования уплотнительных элементов из графитовой фольги, определено удельное усилие прессования для получения уплотнительных элементов заданной плотности. Установлены показатели по удельной прочности полученных прокладок при сжатии.

Выводы. Полученные результаты исследований могут быть использованы для создания опытного производства уплотнительных прокладок из ТРГ на отечественных предприятиях соответствующего профиля.

Ключевые слова: терморасширенный графит, атомные электростанции, технологическое оборудование, уплотнительные элементы. 